\title{
MODEL PEMBELAJARAN INQUIRY DALAM PENINGKATAN PRESTASI BELAJAR IPS TERPADU
}

\author{
Samsul Susilawati \\ UIN Maulana Malik Ibrahim Malang
}

\begin{abstract}
General problems faced by most of teacher to promote their learning are how to develop non-conventional learning strategy to motivate their students. It's difficult to develop learning strategy that can promote student all of competencies, promote student values such a democratic and responsibilities values. It's also difficult to develop learning strategy that make society as a learning resource. Along with the development of society and the advancement of technology, teachers are required to be more creative in setting up and designing the learning model. Inquiry learning model requires students to think smart, creative, participative, prospective and responsible. Inquiry learning model is believed to be able to change the learning process from teacher centered to student centered learning. This model roles the students become more active while teachers as facilitators and motivators in the learning process.
\end{abstract}

Key words: Inquiry Learning Model

\section{A.Hakikat Belajar dan Faktor yang Mempengaruhi Belajar}

Berbicara tentang belajar dan pembelajaran adalah berbicara tentang sesuatu yang tidak pernah berakhir sejak manusia ada dan berkembang di muka bumi ini sampai akhir jaman nanti. Belajar adalah suatu aktivitas atau suatu proses untuk memperoleh pengetahuan, meningkatkan keterampilan, memperbaiki perilaku, sikap, dan mengokohkan kepribadian. Dimana dalam konteks ini seseorang menjadi tahu, paham, serta mampu untuk mengembangkan sesuatu yang belum pernah ia ketahui sebelumnya.

Dalam proses belajar dan pembelajaran, manusia harus mempunyai suatu cara atau langkah-langkah untuk mengolah, mengembangkan, dan menerapkan berbagai macam pengetahuan-pengetahuan yang telah diperolehnya melalui proses belajar. Ini berkaitan dengan metode-metode yang digunakan dalam pembelajaran. 
Metode pembelajaran adalah seluruh perencanaan dan prosedur maupun langkahlangkah kegiatan pembelajaran termasuk pilihan cara penilaian yang akan dilaksanakan. Metode pembelajaran dapat dianggap sebagai sesuatu prosedur atau proses yang teratur, suatu jalan atau cara yang teratur untuk melakukan pembelajaran.

Masalah umum yang dihadapi oleh sebagian besar guru pelajaran IPS dewasa ini adalah kurangnya kemauan dan kemampuan untuk mengembangkan model pembelajaran non-konvensional yang dapat membangkitkan gairah belajar, mengembangkan seluruh potensi anak didik, menanamkan kehidupan yang demokratis, dan menjadikan masyarakat sebagai sumber belajar. Seiring dengan perkembangan masyarakat dan kemajuan teknologi, guru dituntut untuk lebih kreatif dalam menyiapkan dan merancang model pembelajaran yang akan dilakukannya. Salah satu model pembelajaran yang dapat mewujudkan adalah model pembelajaran inquiry. Model pembelajaran inquiry menuntut siswa untuk berpikir cerdas, kratif, partisipatif, prospektif dan bertangungjawab.

Direktorat Jenderal Pendidikan Tinggi dalam rambu-rambu S2 Pendidikan Dasar (2006:6) menengarahi bahwa dunia pendidikan sekolah dasar masih dihadapkan pada isu-isu sentral seperti kurangnya inovasi pembelajaran sehingga belum mampu mengentaskan mutu pembelajaran dari paradigma penerusan informasi (content transmission model) dan kurangnya kemampuan guru untuk mengembangkan diri (self-renewal).

Gufron (Masnur Muslich, 2007: 153) menyatakan bahwa salah satu kendala yang dihadapi oleh guru IPS, adalah bahwa guru IPS berhadapan dengan materi yang memiliki cakupan yang sangat kompleks. Hal ini 
menyulitkan guru untuk menstruktur dan mensistimalisasikan materi pelajaran secara cermat berdasarkan tipe isi dalam kaitannya dengan tujuan pembelajaran. Menstruktur dan mensistimalisasikan materi pelajaran secara cermat sesuai dengan sasaran belajar bukanlah tugas yang mudah. Tugas ini memerlukan pengetahuan yang cukup baik tentang perencanaan pembelajaran. Di sisi lain, ternyata kemampuan guru dalam merencanakan dan mengimplementasikan kurikulum belom memuaskan. Kondisi pembelajaran yang demikian sejalan dengan apa yang dikemukakan oleh Arief Achmad (2004: 1) yang mengungkapkan beberapa kelemahan dalam pembelajaran IPS di sekolah antara lain guru tidak dapat meyakinkan siswa untuk belajar IPS lebih bergairah dan bersungguh-sungguh dan guru lenih mendominasi siswa (teacher centered).

Model pembelajaran konvensional yang selama ini digunakan model pembelajaran yang bersifat teacher centered yaitu pembelajaran yang berpusat pada guru. Pada proses pembelajaran guru lebih bersifat aktif sedangkan siswa cenderung pasif. Siswa menerima apa yang telah diajarkan dan melaksanakan apa yang ditugaskan oleh guru. Dengan pembelajaran yang demikian siswa merasa sangat jenuh dengan kegiatan yang sama dari hari kehari. Terbukti dengan sikap yang nampak pada diri para siswa, misalnya siswa cenderung pasif, mengeluh apabila diberi tugas, dan merasa terbebani oleh pelajaran. Kondisi semacam ini semakin memperkuat perlunya diterapkan model pembelajaran yang lebih variatif, misalnya penerapan model pembelajaran inquiry. Model pembelajaran inquiry diyakini mampu mengubah proses pembelajaran menjadi pembelajaran yang bersifat student centered yaitu proses 
pembelajaran yang memerankan siswa lebih aktif sedangkan guru memotivasikan diri sebagai fasilitator dan motivator dalam proses pembelajaran.

Belajar merupakan suatu proses yang ditandai dengan adanya perubahan pada diri seseorang. Perubahan yang merupakan hasil dari belajar dapat ditimbulkan dalam berbagai bentuk seperti pada pengetahuan, sikap dan tingkah laku, keterampilan, kemampuan dan kecakapan serta perubahanperubahan pada aspek-aspek lainnya yang ada pada diri seseorang yang melakukan belajar.

Menurut Ahmadi dan Supriyono (1990: 121) belajar adalah suatu proses usaha yang dilakukan individu untuk memperoleh suatu perubahan tingkah laku yang baru secara keseluruhan sebagai hasil pengalaman individu itu sendiri dalam interaksi dengan lingkungan. Perubahan yang terjadi dalam aspek-aspek kematangan, pertumbuhan dan perkembangan tidak termasuk dalam pengertian belajar. Sudjana (1990: 5) mengemukakan bahwa belajar adalah suatu perubahan yang relatif permanen dalam suatu kecenderungan tingkah laku sebagai hasil dari praktek atau latihan. Perubahan tingkah laku individu sebagai hasil belajar ditunjukkan dalam berbagai aspek seperti perubahan pengetahuan, pemahaman, persepsi, motivasi, atau gabungan dari aspek-aspek tersebut. Selanjutnya G.A. Kimble dalam Lisnawaty (1993: 38) mengemukakan bahwa belajar adalah perubahan yang relatif menetap dalam potensi tingkah laku yang terjadi sebagai akibat dari latihan dengan penguatan dan tidak termasuk perubahan-perubahan karena kematangan, kelelahan atau kerusakan pada susunan saraf. 
Dari beberapa pendapat di atas dapat disimpulkan bahwa belajar adalah suatu proses perubahan tingkah laku seseorang yang telah mengalami praktek atau latihan yang dapat diamati dari kemampuan aktual dan potensi baru yang di peroleh melalui usaha, dan bukan perubahan tingkah laku yang disebabkan oleh proses pertumbuhan yang bersifat fisiologis atau kematangan. Perubahan tingkah laku akibat proses belajar meliputi aspek pengetahuannya, keterampilan, maupun sikapnya.

\section{B. Model Pembelajaran Inquiry}

Inquiry berarti suatu rangkaian kegiatan belajar yang melibatkan secara maksimal seluruh kemampuan siswa untuk mencari dan menyelidiki secara sistematis, kritis, logis, analitis, sehingga mereka dapat merumuskan sendiri penemuannya dengan penuh percaya diri. Pembelajaran inquiry beriorientasi pada keterlibatan siswa secara maksimal dalam proses kegiatan belajar, keterarahan kegiatan secara maksimal dalam proses kegiatan belajar, mengembangkan sikap percaya diri pada siswa tentang apa yang ditemukan dalam proses inquiry.

Inquiry dilakukan melalui langkah-langkah seperti observasi dan pengukuran, hipotesis, interprestasi, dan penyusunan teori. Inquiry memerlukan eksperimentasi, refleksi, dan pengenalan terhadap kekuatan dan kelemahan metode yang digunakan (Hebrank, 2000). Inquiry berkaitan dengan aktivitas dan keterampilan aktif yang fokus pada pencarian pengetahuan atau pemahaman untuk memuaskan rasa ingin tahu (Haury, 1993).

Dalam bidang pembelajaran, dikenal metode pembelajaran yang disebut Inquiry Based Teaching (IBT), yaitu sebuah metode pembelajaran yang menjadikan 
guru untuk menciptakan situasi yang memposisikan siswa sebagai ilmuwan. Siswa mengambil inisiatif untuk mempertanyakan suatu fenomena, mengajukan hipotesis, melakukan observasi di lapangan, menganalisis data, dan menarik simpulan, serta menjelaskan temuannya itu kepada orang lain. Jawaban yang diharapkan atas pertanyaan tersebut tidak bersifat tunggal tetapi jamak. Yang terpenting adalah bahwa dalam mencari jawaban, siswa bekerja dengan menggunakan standar tertentu yang jelas sehingga hasilnya dapat dipertanggungjawabkan. Oleh karena itu, dimungkinkan siswa mengintegrasikan dan mensinergikan berbagai disipin ilmu dan metode yang berbeda (Budnitz, 2003).

MenurutBerman dan Kotar (1989) untuk menerapkan metode Inquiry Based Teaching (IBT) ada beberapa tahapan sebagai berikut:

\section{Ekplorasi}

Pada tahap ini, siswa bebas menemukan dan memanipulasi materi pelajaran. Pengajaran tentang konsep belum diberikan, sehingga siswa bebas bereksplorasi dan mengajukan pertanyaan atau gagasan. Dalam hal ini siswa, baik secara individu maupun kelompok melakukan observasi dan mencatat data. Guru berperan sebagai fasilitator untuk mengamati, mengajukan pertanyaan, dan memberikan saran. Tahap ini disebut tahap penemuan terbimbing yang dilakukan oleh guru.

\section{Pengenalan Konsep.}

Pada tahap ini, siswa dibawah bimbingan guru, mengorganisasikan data yang telah dikumpulkan dan mencari pola yang muncul. Selanjutnya, mereka saling menyampaikan dan membandingkan temuannya dengan teman atau kelompok lain. Pada tahap ini, guru dapat memberikan tambahan informasi yang berupa referensi atau sumber-sumber lain yang relevan. Selanjutnya siswa dapat melanjutkan pencariannya atau melakukan penguatan atas temuannya itu dengan 
cara membaca referensi tersebut dan mengkomunikasikannya kepada guru atau teman lain.

\section{Aplikasi Konsep}

Pada tahap ini, siswa diberikan permasalahan yang harus mereka pecahkan dengan menggunakan informasi yang diperoleh melalui penemuan di lapangan dan membaca referensi. Pada tahap ini biasanya guru memberi aktivitas tambahan yang dapat memberi penguatan hasil belajar sebelumnya.

Menurut Hamzah (2008), pembelajaran dengan pendekatan konstruktivistik meliputi 4 tahapan yaitu:

1. Apersepsi. Menghubungkan konsepsi awal, mengungkapkan pertanyaanpertanyaan dari materi sebelumnya yang menjadi dasar perbandingan serta landasan untuk menerima ide baru.

2. Eksplorasi. Menggali, menyelidiki dan menemukan konsep yang lebih banyak yang dapat dijadikan bahan untuk menambah informasi dan pengetahuan.

3. Diskusi dan Penjelasan Konsep. Mengkomunikasikan hasil penyelidikan dan tamuan dari siswa, kemudian mendiskusikan bersama dan peran guru untuk memfasilitasi dan memotivasi kelas.

4. Pengembangan dan Aplikasi. Konsep awal yang telah ditemukan dari berbagai penyelidikan kemudian dikembangkan, merumuskan kesimpulan, serta menerapkannya melalui pengerjaan tugas atau proyek.

Beberapa tahapan diatas dapat diterapkan dalam pembelajaran di Madrasah Ibtidaiyah Sunan Kalijaga khususnya pada kelas IV yang melibatkan satu kelas dengan tema pokok mengenal pentingnya koperasi dalam meningkatkan kesejahteraan masyarakat. Dalam mata pelajaran IPS, guru terlebih dahulu menyampaikan teorinya secara garis besar kemudian dilanjutkan dengan aplikasinya 
dalam praktikum. Dalam kegiatan praktikum siswa diberikan project work dari guru, kemudian guru memberikan kebebasan kepada siswa untuk menyelesaikan project work nya sesuai dengan kreativitas masing-masing. Dengan kegiatan seperti ini menjadikan siswa lebih kreatif dan produktif sehingga memacu untuk bersaing dalam meningkatkan prestasi.

Menurut Hebrank (2000) metode pembelajaran Inquiry Based Teaching (IBT) bermanfaat bagi siswa di Madrasah Tsanawiyah Sunan Kalijaga Malang karena:

1. Materi pelajaran yang dipelajari berkaitan dengan pengalaman seharihari siswa yang kadangkala menimbulkan keingintahuan mereka,

2. Dapat membuat siswa aktif karena Inquiry Based Teaching (IBT) meminimalisir metode ceramah,

3. Dapat mengakomodasikan perbedaan perkembangan siswa,

4. Metode penilaian pada Inquiry Based Teaching (IBT) memungkinkan siswa memperlihatkan kompetensi dengan berbagai cara,

5. Dapat mensinergikan berbagai mata pelajaran dengan metode belajar yang berbeda,

6. Dapat mengembangkan kompetensi komunikasi siswa karena mereka harus menyampaikan temuannya dengan cara yang mudah dipahami

7. Dapat mengembangkan berpikir kritis siswa,

8. Dapat membuat siswa lebih mandiri.

Sedangkan manfaat bagi pendidik (guru), dapat menciptakan kesempatan untuk mempelajari bagaimana pikiran siswa bekerja. Pemahaman tersebut dapat digunakan untuk menciptakan situasi belajar dan memfasilitasi mereka dalam memperoleh pengetahuan. Menurut Budnitz (2003), ketika menerapkan Inquiry Based Teaching (IBT)guru dapat mengetahui:

1. Kapan memberi dorongan,

2. Petunjuk apa yang dapat diberikan kepada setiap siswa,

3. Apa yang tidak perlu diberikan kepada siswa,

4. Bagaimana membaca perilaku siswa ketika mereka sedang bekerja, 
5. Bagaimana membantu siswa berkolaborasi dalam memecahkan masalah secara bersama-sama,

6. Kapan pengamatan, hipotesis, atau eksperimen bermakna bagi siswa,

7. Bagaimana mentoleransi ambiguitas (yang mempunyai makna ganda),

8. Bagaimana memanfaatkan kesalahan secara konstruktif,

9. Bagaimana membimbing siswa secara tepat.

Metode ini selaras dengan teori konstruktivistik, dimana dalam pembelajaran berdasarkan konstruktivistik memberikan kesempatan kepada siswa untuk mengungkapkan gagasan secara eksplisit, memberi pengalaman yang berhubungan dengan gagasan yang telah dimiliki oleh siswa, sehingga siswa terdorong untuk membedakan dan memadukan gagasan tentang fenomena yang menantang siswa. Pendekatan ini mendorong siswa dapat berpikir kreatif, imajinatif, refleksi tentang model dan teori, mengenalkan gagasan-gagasan pada saat yang tepat. Mencoba gagasan baru, mendorong siswa untuk memperoleh kepercayaan diri. Dengan demikian pendekatan konstruktivistik memberikan lingkungan belajar yang kondusif yang mendukung siswa mengungkapkan gagasan, saling menyimak, dan menghindari kesan selalu ada satu jawaban yang benar. Sehingga, metode Inquiry Based Teaching (IBT) dengan pendekatan konstruktivistik dalam pembelajaran IPS di Madrasah Tsanawiyah Sunan Kalijaga dapat memberikan motivasi kepada siswa untuk lebih kreatif, inovatif, dan produktif serta mampu untuk meningkatkan prestasi belajar siswa.

\section{Penerapan metode Inkuiri dalam pembelajaran IPS}

Belajar merupakan suatu proses dimana tingkah laku diubah melalui praktek atau latihan. Dengan belajar manusia melakukan perubahan-perubahan 
kualitatif-kualitatif individu sehingga tingkahlakunya berkembang. Perubahan inilah yang merupakan hasil belajar. Perubahan itu terjadi pada diri individu sebagai tingkah laku yang baru yang bersifat tetap pada akhirnya akan melahirkan kemampuan bagi seseorang dalam menyelesaikan permasalahan yang dihadapinya.

Kemampuan itulah yang terwujud dalam prestasi belajar. Hal ini sesuai dengan pendapat yang dikemukakan oleh Adinegoro (1980: 3) bahwa prestasi belajar adalah hasil yang dicapai dari segala pekerjaan yang berhasil dan menunjukkan hasil kecakapan manusia setelah melalui proses belajar. Sehingga dikatakan bahwa prestasi belajar IPS merupakan suatu perubahan yang terjadi dalam diri seseorang setelah melakukan suatu proses belajar IPS. Adanya perubahan itu tampak pada adanya kemampuan yang dimiliki siswa dalam menyelesaikan pertanyaan/persoalan dan tugas yang diberikan oleh guru sebagai suatu prestasi yang dihasilkan. Dengan demikian prestasi belajar menggambarkan keberhasilan suatu proses belajar yang dapat mencerminkan tingkat kemampuan siswa

$$
\text { dalam menyerap pelajaran. }
$$

IPS merupakan mata pelajaran yang mempelajari fakta-fakta. Materi

pembelajaran IPS juga sangat banyak dan luas sehingga siswa terkadang sulit untuk mengingat materi dalam pelajaran tersebut. Agar mudah diingat sangat penting untuk membermaknakan suatu materi. Salah satu cara yaitu dengan menemukan sendiri jawaban atas suatu pertanyaan yang telah dirancang oleh guru.

Berdasarkan uraian di atas, maka prestasi belajar IPS dapat diartikan sebagai hasil belajar IPS yang diperoleh setelah menempuh proses 
belajar IPS yang dilambangkan dengan nilai hasil belajar. Jadi prestasi belajar IPS adalah bukti keberhasilan usaha yang dicapai dalam belajar IPS.

\section{DAFTAR PUSTAKA}

Bogdan, Robert C. dan Sari Knopp Biklen, 1990.Riset Kualitatif untuk Pendidikan: Pengantar Teori dan Metode. Jakarta: Dirjend Perguruan Tinggi Depdikbud.

Bean, R., 1995. Membantu anak agar berhasil di sekolah. Meitasari Tjandrasa (terj.). Jakarta: Bina Aksara.

Budiningsih, C. Asri. 2005. Belajar dan Pembelajaran. Jakarta: Penerbit Rineka Cipta.

Cohen, L., Manion, L., \& Morrison, K. 2011. Research Methodslin Educations. New York: Routledge.

Creswell, J.W. 2009. Research Design: Qualitative, Quantitative, and Mixed Methods Approaches. Third Edition. California: Sage.

Djajadiasatra, 1981. Metode-Metode Mengajar. Bandung : Angkasa

Felder, R.M., 1988. Learning Styles and Teaching Styles in Engineering Education. Engineering Education 78 (7) 674-781.

Haury, L. David. 1993. Teaching Science through Inquiry. Columbus, OH: ERIC Clearinghouse for Science, Mathematics, and Environment Education. (ED359048).

Joyce and Weil, 1986. Models of Teaching Prentice: Prentice/Hall International

Joyce And Weil. 1986. Models of Teaching. Prentice/Hall International

Latuheru, 1988. Media Pembelajaran Dalam Proses Belajar Mengajar Masa Kini. Jakarta : Depdikbud

Makmun, H.A.S, 2007. Psikologi Kependidikan. Jakarta: Rineka Cipta

Muhaimin, 1996. Strategi Belajar Mengajar. Surabaya : CV. Citra Media

Roestiyah, 1991. Strategi Belajar Mengajar. Jakarta : Rineka Cipta

Suparno, Paul. 1997. Filsafat Konstruktivisme dalam Pembelajaran. Yogyakarta: Penerbit Kanisius.

Slamento, 1993. Proses Belajar Mengajar Dalam Proses Kridit Semester. Jakarta : Bumi Aksara. 